\title{
The Informal Sector and the World Economy: Notes on the Structure of Subsidised Labour
}

\section{Alejandro Portes}

\section{Introduction}

The study of urbanisation, together with that of migration, has placed its practitioners at the crossroads of two major strands of 'developmental' thought. One concerns the anthropological and sociological literature exploring how the poor survive under the constraints of underdeveloped capitalist economies. The other is the historical and economic literature on state policies, unequal exchange, and the system insertion of countries within world capitalism. The line of reasoning I wish to explore in this paper offers some promise of articulating both levels in a manner which goes beyond the perennial recognition that 'micro' and 'macro' structural phenomena are somehow related. The relevance of this issue to the new emphasis placed by international agencies on 'basic needs' as an approach to development lies in clarifying the way such 'needs' have been taken care of so far in many underdeveloped countries and, more importantly, the way such strategies for survival articulate with the requirements of the capitalist economy.

My subject in this paper is the 'informal economy' or 'informal sector'. My argument can, in part, be interpreted as a defence of the concept against accusations of irrelevance or academic voguism. On the contrary, I suggest that the concept of the 'informal economy' is fundamental to understanding the operations of capitalism as a world phenomenon and constitutes a missing element in contemporary 'world-system' formulations of relationships between core and periphery. The data on which this proposition is based come, primarily, from a series of recent field studies conducted in different countries of Latin America. 1

Earlier formulations defined the informal economy as the way the marginal poor took care of themselves in the city. Squatter settiements, which served as loci for much informal economic activity, lost the stigma of the past since they did not represent problems, but 'solutions to the problem'. Later studies observed, however, that the informal sector was more than an exercise in'-self-preservation: the 'marginals' turned out to be profoundly integrated in the production, distribution, and consumption structures of the city.

1 See, for example, Roberts in Portes and Browning (eds.) 1976; Mangin 1967: Uzzell in Cornelius and Trueblood (eds.) 1974; Peat tic 1968; Leeds and Leeds in Field (ed.) 1969; Lomnitz 1977).
Studies in Ciudad Guayana, Rio de Janeiro, and Mexico City, among others, showed how close was the interdependence between shantytown economies and those of the broader city.

Thsse studies went on to note the profound dependence of informal economic activities on decisions, events, and resources in the formal sector. This assertion holds when seen from the point of view of the individual shantytown worker or petty entrepreneur. From the point of view of the dominant economic system, however, the opposite is more accurate. The organisation of 'formal' capitalism in peripheral underdeveloped countries appears to be dependent on the informalsector, and this dependence extends beyond the way workers in that sector take care of their own needs. Further, the hypothesis can be advanced that functional effects of informal economies reach, through a series of interlinked mechanisms, to the very centres of capitalist accumulation.

\section{Wage-levels in centre and periphery}

It is generally accepted that the percentage of the labour force of advanced industrial countries which i ; fully 'proletarianised'-i.e. fully dependent for its reproduction as labour on monetary wages-is higher than that in peripheral countries. It is also generally agreed that real wage levels in the core capitalist countries are higher, on average, than those in the periphery for exactly the same type and amount of work.

Why labour in core economies is more dependent on wages and why those wages are higler come down, in the ultimate analysis, to the same thing. Though the argument can take many forms, the recent formulation by Alain de Janvry (1976-77) is the most useful for present purposes :

Profits to capital depend on maintenance of wages paid to workers at a minimum relative to productivity. Actualisation of moncy profits depends, however, on the sale of the product. The process of capital accumulation entails a constant growth in productive capacity, a trend which constantly outstrips demand. The market for core capitalist production is aiso, by and large, a "core' market. Expanding that market to avert or attenuate crises of over-production means putting more money in the hands of the mass of consumers. Pressures to expand the internal market thus lead to incorporation of remaining 'subsistence redoubts' into the money economy and to higher 
wages. It is this organic integration of profits and wages in core economies which, in part, counteracts the downward pressure on wages. Surplus obtained by exploiting workers can not be actualised without selling the product to other workers.

This 'organic' nexus disappeal's under peripheral capitalism for the fundamental reason that the hegemonic sector in these economies produces for export. Profits, in other words, are actualised by sale in markets abroad, rather than within the country. While domestic enterprises and branches of multinational enterprises also produce for a restricted internal market, their existence is ultimately dependent on export earnings. Nor is this situation limited to countries exporting agricultural products and materials; the more industrialised peripheral countries have also become increasingly dependent on manufactured exports to sustain their internal economies. $^{2}$

Under these conditions, downward pressure on wages is not counteracted by pressures to expand the internal market. The logic of peripheral capitalism is one where profits are maximised by keeping labour costs at a minimum. Cheap labour is indeed what gives many peripheral countries a 'competitive edge' in the international market. The pressure on wages is reflected in two aspects: first, actual restrictions in the consumption levels of workers and, second, a continuous attempt to cheapen their consumption, that is, to transfer part of the costs of their reproduction to other economic units.

\section{Labour costs}

The question of why wage levels in central and peripheral capitalist economies must differ is not identical to that of how peripheral labour costs are kept low. Two strategies are suggested by the existing literature: the first is the use of a reserve army of labour. This strategy tends to inhibit the upward movement of wages, thus keeping consumption levels low. The second consists of subsidising wages paid by capitalist enterprises through the use

2 For Brazil, see Bacha (1976) and Baer (1975); for Mexico Biair (1974) and Rhodes in Wilber (ed.) (1973). of workers from the rural subsistence sector. Workers reared in villages, under subsistence conditions, come to work for wages in mines, plantations, and urban plants, and the wages paid cover only the reproduction of the worker while employed. Collectively, moreover, capitalist enterprises save the costs of supporting workers during their early unproductive years (Meillassoux 1972; Meillassoux cited in Clammer in Oxaal, Barnett and Booth (eds.) 1975).

This 'subsidy' of subsistence to capitalist economies is compounded when the worker ceases to be useful and is forced to return to the village. By shifting replacement and welfare costs onto the subsistence sector, capitalist enterprises in the periphery save a significant part of the real wage bill. In other words, the co-existence of subsistence and capitalist modes of production enables capitalist enterprises to exploit not only the labour of the worker, but that of his kin in the village, as the latter are forced to provide for his needs during periods of idleness and old age.

The reserve army and subsistence transfer strategies do not suffice, however, to explain fully the situation in many peripheral societies. Latin American countries, in particular, present a situation where subsistence economies have a diminishing and, in some cases, vestigial importance. For most Latin American countries, it would be risky indeed to affirm that villages producing for subsistence provide the bulk of labour for enterprises in the capitalist sector, or that they fully subsidise its welfare costs. As to the reserve army argument, it should be remembered that a considerable proportion of employed labour in the formal capitalist sector consists of skilled workers. More importantly, workers in the formal sector are those to which protective legislation most directly applies and those most capable of deriving support from existing labour organisations.

Despite the restricted effectiveness of the above mechanisms in many peripheral countries, wages continue to be comparatively low, even for skilled labour. Cases such as Brazil, provide a compelling illustration of the disparity (see below).

Comparative Wage Scales

(US \& per hour-1975)

\begin{tabular}{|c|c|c|c|c|c|c|c|c|}
\hline & & Brazil & Japan & Germany & Belgium & UK & Italy & USA \\
\hline Unškilled labour & .. & $0 \cdot 24$ & $0 \cdot 74$ & $1 \cdot 27$ & $1 \cdot 34$ & 0.96 & 0.67 & $3 \cdot 00$ \\
\hline Light assembly .. & . & $0 \cdot 32$ & $0 \cdot 65$ & $1 \cdot 40$ & $1 \cdot 42$ & $0 \cdot 82$ & $0 \cdot 72$ & $2 \cdot 89$ \\
\hline Machine operator & .. & 0.68 & 0.68 & $1 \cdot 50$ & $1 \cdot 64$ & $1 \cdot 01$ & 0.86 & $3 \cdot 24$ \\
\hline Maintenance mechanio & .. & 0.65 & $0 \cdot 78$ & $1 \cdot 60$ & $1 \cdot 83$ & $1 \cdot 42$ & 0.92 & $3 \cdot 29$ \\
\hline Toolmaker . . . . . & . & 0.81 & 0.79 & $1 \cdot 73$ & $1 \cdot 87$ & 1.61 & $1 \cdot 02$ & $5 \cdot 03$ \\
\hline
\end{tabular}

Source A. Brown and J. P. Ford, Brazil: Today's Business Opportunity, London, 1975:124 
An additional mechanism must exist. Though political repression of working class demands has certainly proved effective in the short-run, a more stable and less overt mode of controlling labour costs is needed. The means to sustain effective downward pressures on labour costs can not be provided solely by an economic sector of decreasing relative importance, such as subsistence agriculture, but requires one whose growth accompanies that of capitalism itself.

\section{Class structure and the informal economy}

For purposes of the argument, the class structure of a peripheral society can be crudely divided into four groups:

Class 1 Owners, managers, and top-level state administrators

Class 2 Non-manual workers: clerks, technicians and salaried professionals

Class 3 Manual workers in public and private enterprises

Class 4 Informal sector workers

The first three classas comprise the formal sector. The interests of the first class are, however, structurally contrary to those of the other two. Class 1 members are dependent, directly or indirectly, on the rate of profit. While for some this may be tied to expansion of the internal market, the structure of peripheral capitalism leads to the dominance of exportoriented enterprises and interests. This means an unmitigated downward pressure on the portion of the product going as salaries and wages to Classes 2 and 3. The increase in the share of the product of formal capitalist enterprises going as profits to Class 1 can thus be managed in two ways: dacreasing the consumption levels of Classes 2 and 3 or decreasing the costs of inputs consumed by these classes.

Individual actors and enterprises in the informal sector have been defined according to a number of characteristics. Bryan Roberts (1976) however, identifies their two most significant characteristics. First, they are labour intensive; second, they avoid formal state supervision and regulation. These combine substantially to reduce the 'input' costs of whatever goods or services are produced, thereby cheapening the price of the cutputs. Long and strenuous hours are contributed by the individual himself, by unpaid kin, and by others in his informal network of friends and acquaintances. Absence of state supervision means, first of all, greater ease in avoiding taxation; it also means avoiding the rigidities of labour legislation. Informal sector workers are seldom paid the official minimum wage, nor do they have access to health insurance, unemployment compensation, old-age pensions, and other indirect benefits. Hiring and laying off is done on a much more casual basis, according to need.
The 'competitive edge' of the informal sector in relation to the formal one in peripheral countries parallels the 'edge' that the peripheral country as a whole has in relation to core capitalist nations in the international economy. In both cases, it is based on access to cheaper sources of labour.

Depending on the specific situation, the relationship between the classes above may be defined as one in which Class 1-the owners-use Class 4-the informal sector-against the intermediate classes, or as one in which Class 1 allows Classes 2 and 3 to exploit Class 4 , thereby cheapening their costs of consumption and reducing upward pressure on wages. In whatever version, the fundamental point is that the informal sector subsidises part of the costs of formal capitalist enterprises in peripheral countries, enabling them to enforce comparatively low wages on their own labour. The basic needs of formal sector workers are partially met by goods and services produced using unpaid or more cheaply paid informal labour. Paralleling the mechanisn of subsistence transfer, but in a far more diversitied and complex manner, the capitalist sector is thus able to exploit not only the work energy of the worker, but that of his kin, neighbours, and friends as well.

\section{Uses of informal labour}

Let us consider the hypothetical case of a worker employed in a soft drink plant in a large Latin American city. He lives in a fairly good house in one of the local shantytowns. He probably could afford rented rooms or even a small house in the city, but he would get less comfortable quarters for a high price. In the shantytown, he pays no rent. He probably bought the lot through informal contract and built the house with materials purchased locally over a period of time. Let's assume he has a wife, three children, an unemployed sister, and an aging mother. The children go to a state school. To supplement the family income, the women set up a little business. It might be a front-room store in the house or a cheap food stand somewhere in the city. The initial small investment comes from the man's wages. The family also raises a pig or two and a few chickens.

Food is seldom bought in the supermarket, but locally from petty merchants who give credit. Eggs, milk, and other products may be bought from individual neighbours. Vegetables and meat come, at times, from the village. Clothing is almost always second-hand, bought cheap or given by families in the city and refitted by the women or the shantytown tailor. The house has electricity, a radio, and television. Electricity is either bought legally, purchased from a neighbour, or tapped illegally. Appliances and other items of furniture might have been bought in longterm instalments from a store in town; most likely, however, they were obtained second-hand through 
informal contacts and repaired locally. Appliance repairs and all sinilar services are always done in small shops in the shantytown or linked through social contacts with it.

The lives of wage-workers in the private and state sectors in peripheral countries are conditioned at every step by their relationships with the informal economy. Though those workers are also consumers of formal sector goods, a substantial proportion of their needs are satisfied by informal sources. This is especially true of services but also extends to goods, such as food and refurbished durables. The relative cheapness of these goods and services is what enables the worker to meet his basic needs and even save, within the constraints of a meagre wage. His savings may, in turn, initiate other family-based informal enterprises.

The shantytown or squatter settlement is the physical counterpart and the most common living environment of the class of informal sector workers. Its very size has forced a rupture in the rules of conventional urban land speculation, reducing housing costs for both informal and formal sector workers (Lomnitz 1977; Lomnitz in Portes and Browning (eds.) 1976; Collier 1976; Turner 1968; Mangin 1967). Shantytown housing thus represents a major indirect subsidy to wages, passed on and ultimately benefiting owners in the formal sector.

This subsidy, like most others provided by the informal economy, depends on the physical contiguity of formal and informal sector workers. In the shantytown the two groups are indistinguishable, with the same individuals frequently alternating between periods of formal and informal employment or simultaneously holding jobs in both sectors. At first glance, this symbiotic relationship appears as evidence of the dependence of informal activities on money wages. The opposite is, however, more accurate as the consumption 'yield' of wages is multiplied by informal sources of supply.

This subsidy-to-consumption is not limited to Class 3 workers. The same applies, albeit less directly, to clerks, technicians, and professionals. Though there is less empirical evidence on this point, Class 2 workers appear to make use, in a vast number of ways, of informal sector goods and serviccs. Cheap and abundant domestic labour is but the most visible evidence of the subsidy to middle-class consumption provided by the informal econony. While available studics concentrate on the political symbiosis between the niddle-classes and the shantytown, anyone familiar with Latin American cities knows that access and consumpiion of goods and services outside the formal economy is an everyday practice $\mathrm{i}$ i) middle-class households.
The 'cheapness of labour' for formal capitalist enterprises is thus partly a consequence of the 'cheapness of life'. based in turn on everyday transactions with the informal economy. This subsidy-to-consumption is probably the most important, but not the only role played by informal sector workers.

Not surprisingly, Class 1 owners and managers have reached down to the informal economy in order to by-pass the costs of expanding employment of Class 3 workers. The revival of the 'put-out or 'maquila' system in peripheral shantytowns of Mexico City is a case in point. As described by Lomnitz (1977A) production is farmed out, usually via an intermediary, to shantytown workers receiving less than the ninimum wage and no indirect benefits compensation: In one variant, clothing materials are distributed to women working at home who are paid a piece-rate for finished articles. In another, construction workers are recruited by an informal contractor and organised to perform a particular job. In a third, firms recruit and organise children and women to market brand-name products in the streets.

\section{Conclusion: marginality and the world economy}

The rapid increase in social research on the urban poor', the 'marginals', the 'shantytown', and finally the 'informal sector' in Latin America has helped develop, over a period of a few years, a major body of knowledge about a previously ignored group. At the local level, the picture appears more or less complete, at least in the present conjuncture. However, the articulation of this working-class population within an international economic order remains problematic.

Recent advances in the literature owe much to social scientists wolking close to the field. Researchers repeatedly found that 'marginals' did not form an incrt nuass, but were in fact quite adept at turning their restricted opportunities to advantage. The rationality of the urban poor was highlighted and the mythologies of the past-radical anger and the 'culture of poverty'-effectively discredited.

The next step was the discovery that the economic activities of the "marginal' population were not conducted in isolation, but were in fact closely articulated with those of the dominant cconomy. At this point, the concept of 'informal sector' gained increasing acceptance. Earlier formulations defined the informal sector as interstitial: it operated in the gaps of economic opportunity left by formal enterprises. The theory was that the informal economy owed its dynamism to the still incomplete and imperfect penetration of capitalism in the periphery. A corollary was that the informal economy represented a transitional phenomenon, since the 
growing consolidation of capitalism would eventually deny its raison d'étre.

Later year's have brought no evidence of the weakening of the informal sector and have, in fact, produced new findings indicating that its role in the economy is far more central than originally thought. But while convincingly denying the interstitial character of the informal economy, recent studies still insist that its existence and dynamism are dependent on the formal sector. This argument stands the situation on its head: though there exists a symbiotic relationship between the two, from the standpoint of basic structural arrangements the opposite is the case.

Recent analyses from the world system perspective have shown with great clarity reasons for the sustained peripheral expansion of central capitalist economies (Wallerstein and Hopkins 1977; Wallerstein 1977: 29-40; for an earlier statement see also Magdoff 1969). The argument complements that of de Janvry, summarised above: the need to prevent and attenuate downward turns in core economies leads to sustained pressures for market expansion. This, in turn, means increased proletarianisation of the labour force. A labour force which is proletarianised-that is, fully dependent on money wages--is one which, sooner or later, organises and makes demands. Thus, to the upward pressure on wages created by the economic needs of capital accumulation, are added those created by the political need for social stability.

Co-opting workers in the core economies can only be achieved through transferring costs. According to the theory, capitalism as a world system has been able to achieve market expansion and social stability in the centres by constantly expanding its activities in the periphery. High consumption by some workers has thus been subsidised by sustained exploitation of others.

The theory draws a blank, however, when it comes to explaining how disparities between core and peripheral wages can be indefinitely maintained. It argues, at most, that this depends on the use of a semi-proletarianised labour force whose reproduction is partially subsidised by subsistence enclaves. As seen above, this mechanism is inadequate to explain conditions in Latin America and, probably, in the more industrialised peripheral economies elsewhere.

It is from this perspective that the literature on the dynamics of informal economies acquires its full meaning. The informal sector--a vast network of activities articulated with, but not limited to remaining subsistence enclaves-has implications which go beyond the peripheral countries. Direct subsidies to consumption provided by informal to formal sector workers within a particular peripheral country are also indirect subsidies to core-nation workers and, hence, means to maintain the rate of profit. Thus, through a series of mechanisms wellhidden from public view, the apparently isolated labour of shantytown workers can be registered as gain in the financial houses of New York and London.

The concrete forms that this transfer takes range from low-price raw materials and foodstuffs to an increasing flow of cheap manufactures. Meeting basic and perhaps not-so-basic needs of workers in the fully monetised capitalist sectors is a process partially dependent on the labour of workers whose basic needs are either not met or met outside the money economy. It is this situation which raises doubts about naive policies designed to increase the standard of living' of the poorest (informal) sector workers in underdeveloped countries or incorporate them fully into the money economy.

\section{References}

Bacha, Edmar, 1976, Os Mitos de Uima Decada, Paz e Terra, Rio de Janeiro

Baer, Werner, 1975, 'La reciente experiencia brasilēna de desarrollo: una interpretación', Revista Paraguaya de Sociologia 34

Blair, Calvin P., 1974, "Mexico in the World Economy', Current History, May

Collier, David, 1976, Squatters and Oligarchs. Authoritarian Rule and Policy Change in Peru, Johns Hopkins University Press, Baltimore

Janvry, Alain de, 1976-77, 'Material Determinants of the World Food Crisis', Berkeley Journal of Sociology 21

Leeds, Anthony and Elizabeth, 1969, 'Brazil and the Myth of Urban Rurality: Urban Experience, Work, and Values in "Squatments" of Rio de Janeiro and Lima' in A. J. Field (ed.), City and Country in the Third World, Schenckman, Cambridge (Mass.)

Lomnitz, Larissa, 1976, 'Migration and Network in Latin America' in Alejandro Portes and Harley L. Browning (eds.), Current Perspectives in Latill Alnerican Urban Research, Institute of Latin American Studies and University of Texas Press, Austin

Lomnitz, Larissa, 1977, Networks and Margindity; Life in a Mexican Shantytown, Academic Press, New York, 1977

Lomnitz, Larissa, 1977A, 'Mechanisms of Articulation between Shantytown Settlers and the Urban System', paper presented at the Symposium on 'Shantytowns', The Wenner-Gren Foundation, Burg Wartenstein, Austria 
Magdoff, Harry, 1969, The Agc of Imperialism, Monthly Review Press, New York

Mangin, William, 1967, 'Latin American Squatter Settlements: A Problem and a Solution', Larin Aurerican Research Review 2

Meillassoux, C., 1972, From Reproduction to Production', Economy and Socicty 1

Meillassoux, C., 1975, 'Imperialism as a Mode of Reproduction of Labour Power' cited in John Clammer, 'Economic Anthropology and the Sociology of Development' in Ivar Oxaal, Tony Barnett, and David Booth, (eds.), Beyourl the Sociology of Development: Economy and Society in Latin America and Africa, Routledge and Kegan Paul, London

Peattie, Lisa R., 1968, The View from the Barrio, University of Michigan Press, Ann Arbor

Rhodes, Robert I., 1973, Mexico-A Model for Capitalist Development in Latin America?' in Charles K. Wilber (ed.), The Political Economy of Development and Underdevelopme'mt, Random House, New York
Roberts, Bryan, 1976, 'The Provincial Urban System and the Process of Dependency' in Alejandro Portes and Harley L. Browning (eds.), Cirrent Perspectives in Latin American Urban Research, Institute of Latin American Studies and University of Texas Press, Austin

Turner, John F. C., 1968, 'Uncontrolled Urban Settlement: Problems and Policies', International Social Development Review 1

Uzzell, Douglas, 1974, 'The Interaction of Population and Locality in the Development of Squatter Settlements in Lima' in Wayne A. Cornelius and Felicity M. Trueblood (eds.), Latin American Urban Research Vol. 4, Sage Publications, Beverley Hills

Wallerstein, Immanuel, 1977, 'Rural Economy in Modern World Society', Studic's in Comparctive International Desclopune'ut 12

Wallerstein, Immanuel and Terence R. Hopkins, 1977, 'Patterns of Development of the Modern World-System', Review' 1 